\title{
Impact of Dredging on the Water Quality of Igbedi Creek, Upper Nun River, Niger Delta, Nigeria
}

\author{
${ }^{1}$ Seiyaboh, E.I., Ogamba, E.N. and ${ }^{2}$ Utibe, D.I. \\ ${ }^{I}$ Department of Biological Sciences, Faculty of Science, Niger Delta University, Wilberforce Island, Yenagoa, \\ Bayelsa State. \\ ${ }^{2}$ Department of Animal \& Environmental Biology, Faculty of Science, University of Port Harcourt, Rivers \\ State.
}

\begin{abstract}
The impact of dredging on water quality of Igbedi Creek, upper Nun River, Niger Delta was investigated from June 2009 to May 2011. Two locations - Ogobiri (Dredged) and Agoro-Gbene (Un-dredged) were studied. Two locations - Ogobiri (Dredged Location) and Agoro-Gbene (Un-dredged Location) were studied. For the purpose of this study, the selected dredged and non-dredged sites were divided into stations: Ogobiri - $O G O_{1} D A=$ Dredged Area, $O G O_{I \& 2} D S=$ Downstream, OGO ${ }_{1 \notin 2} U S=U p s t r e a m ;$ Agoro-gbene $A G O_{1} D S=$ Downstream, $A G O_{1} M D=$ Midstream, $A G O_{1} U S=U p$ stream. The data revealed significant spatial differences $(P<0.05)$ between the locations in all the water quality parameters measured except for DO, Temp. and $\mathrm{pH}$. There were significant temporal variations as well between the locations in the following parameters: Temperature, Turbidity, Conductivity, $\mathrm{NO}_{3}^{-}, \mathrm{NO}_{2}^{-}, \mathrm{SO}_{4}{ }^{2-}$, and $\mathrm{BOD}_{5}$. The results further showed high increase in values for Turbidity and $\mathrm{NO}_{2}{ }^{-}$in the station immediately downstream of the dredged area but steadily declined downstream. These results are clear indications that dredging significantly affected the water quality of the creek.
\end{abstract}

\section{Introduction}

Dredging activities have the potential to impact the water quality of aquatic systems. Depending upon the nature of the dredged material, its disturbance from the sea bed may lead to changes in the chemical composition of the water. For example many toxicants such as heavy metals and organic contaminants tend to stick to particulate matter and sink to the sediment. Some of these contaminants are very persistent in the sediment and some may change their oxidation state during burial, which alters their solubility. If these sediments are disturbed, the contaminants can be released to the water column and affect marine life (DSE, 2011).

River channels have been destroyed by straightening, dredging, damming, and water withdrawal for irrigation and industrial and domestic uses. Degradation of living systems inevitably follows. Biological diversity in aquatic habitats is threatened; aquatic biota have become homogenized through local extinction, the introduction of alien species, and declining genetic diversity (Moyle and Leidy, R.A. 1992; Whittier et al., 1997).

This research is intended to access the level of impact of dredging operations on the water quality of Igbedi Creek, upper Nun River. The objectives of the research are:

- To assess the physico-chemical characteristics of the surface waters samples of the various stations in the Dredged and Un-dredged sites.

- Compare the data obtained in the Dredged and Un-dredged site and determine the possible impact of dredging on water quality of Igbedi Creek, upper Nun River.

\section{Methodology}

\section{[1]Study Area}

The study was carried out in Igbedi Creek, a tributary of the Upper Nun River in the Niger Delta located between latitude $5^{0} \mathrm{~N} 01^{1}$ and $6^{0} 17^{1} \mathrm{E}$. The stretch of the river is a long and wide meander whose outer concave bank is relatively shallow with sandy point bars (Abowei, 2000). The depth and width of the river vary slightly at different points (Sikoki et. al., 1998). The minimum and maximum widths are 200 and 250 meters respectively. The river is subjected to tidal influence in the dry season. Water flows rapidly in one direction during the flood (May - October). At the peak of the dry season, the direction of flow is slightly reversed by the rising tide. At full tide the flow is almost stagnant.

\section{[2]Field Study \& Collection of Samples}

Two communities were chosen as sample communities for this study. These are: Ogobiri (Dredged Location), in the Sagbama Local Government Area (SALGA) i.e. the community where the dredging is taking 
place, and Agoro-Gbene (Un-dredged Location), also in Sagbama Local Government Area (SALGA) which is a community that is relatively undisturbed. Both communities are located along the Nun River and are both predominantly fishing communities.

For the purpose of this study, the selected dredged and non-dredged sites were divided into stations: Ogobiri $\mathrm{OGO}_{1} \mathrm{DA}=$ Dredged Area, $\quad \mathrm{OGO}_{\mathrm{I} 22} \mathrm{DS}=$ Downstream, $\quad \mathrm{OGO}_{1 \& 2} \mathrm{US}=\mathrm{Upstream} ; \quad$ Agoro-gbene $\mathrm{AGO}_{1} \mathrm{DS}=$ Downstream, $\mathrm{AGO}_{1} \mathrm{MD}=$ Midstream, $\mathrm{AGO}_{1} \mathrm{US}=\mathrm{Upstream}$.

\section{Collection of Water Samples}

Water samples were collected from three (3) points on each of the stations in each study location. Water samples were collected as subsurface water samples at a depth of about $15-20 \mathrm{~cm}$ below surface. The water samples were collected using DO bottles, BOD bottles and 1 litre containers for the measurement of other water quality parameters respectively. The sampling bottles/containers were rinsed three times with the water at the specific sampling spots before the collection of samples. Generally, the samples were collected by lowering the containers by hand below the surface level. The containers were completely immersed in water, and were corked (stoppered) under water. The water samples were fixed and preserved on the site. Winkler 1 \& 11 solutions were added into the water samples for DO; the samples for BOD were stored in ice-cold containers and taken to the laboratory. The water samples were subsequently taken to the laboratory for analysis. The water samples were treated and analysed using methods described by APHA (2011), Onyeike and Osuji (2003).

\section{[3]Analysis of Experimental Data}

The contaminant concentrations found in each of the aquatic media were compared to World Health Organization (WHO) acceptance limits for drinking water (WHO, 2011). The following statistical tools were used to analyzed the data obtained - Analysis of Variance (ANOVA) for water data analysis; Microsoft Excel (2010) for computation of means and standard deviation.

\section{Results And Discussion}

The physico-chemical parameters of water samples for both Ogobiri (Dredged) and Agoro-Gbene (UnDredged) Locations are shown in Tables $1 \& 2$.

The monthly depth values ranged between $0.50 \mathrm{~m}$ and $29.50 \mathrm{~m}$ across the locations and stations. The mean depths were significantly different $(\mathrm{P}<0.05)$ across the stations. There were significant differences $(\mathrm{P}<0.05)$ in mean depth in Ogobiri $(8.50 \mathrm{~m} \pm 0.64)$ and Agoro-Gbene $(7.19 \mathrm{~m} \pm 0.51)$ locations There was no significant $(\mathrm{P}>0.05)$ variation in depth between the locations for dry $(7.36 \mathrm{~m} \pm 0.72,6.34 \mathrm{~m} \pm 0.90)$ and wet $(9.62 \pm 0.72,8.11 \pm 0.91)$ seasons. These values compare favorably with results obtained in other studies in the Nun River. Water depth correlated significantly with Current Velocity, but was inversely related to temperature, turbidity, conductivity and fish species abundance (Otobo, 1993). The mean depth in Ogobiri location was significantly higher than values obtained in Agoro-Gbene location; this can be attributed to the dredging operation in Ogobiri resulting in much higher depths than usual as a result of excessive extraction of sand from the river bottom.

The monthly current velocity values ranged between $0.02 \mathrm{~ms}^{-1}$ and $0.54 \mathrm{~ms}^{-1}$ across the locations and stations. The mean current velocity were significantly different $(\mathrm{P}<0.05)$ across the stations. There were significant difference $(\mathrm{P}<0.05)$ in mean current velocity in Ogobiri $\left(0.17 \mathrm{~ms}^{-1} \pm 0.01\right)$ and Agoro-Gbene $(0.20 \mathrm{~ms}$ $\left.{ }^{1} \pm 0.01\right)$ locations There was no significant $(\mathrm{P}>0.05)$ variation in current velocity between the locations for dry $\left(0.14 \mathrm{~ms}^{-1} \pm 0.01,0.18 \mathrm{~ms}^{-1} \pm 0.01\right)$ and wet $\left(0.19 \mathrm{~ms}^{-1} \pm 0.01,0.22 \mathrm{~ms}^{-1} \pm 0.01\right)$ seasons. The faster current velocity during the flood season and low flow in the dry season are in agreement with Otobo (1995b) and Abowei (2000).

The monthly $\mathrm{pH}$ values ranged between 5.50 and 8.72 across the locations and stations. The mean $\mathrm{pH}$ were significantly different $(\mathrm{P}<0.05)$ across the stations. There was no significant difference $(\mathrm{P}>0.05)$ in mean $\mathrm{pH}$ in Ogobiri $(7.17 \pm 0.01)$ and Agoro-Gbene $(7.26 \pm 0.01)$ locations There was no significant $(\mathrm{P}>0.05)$ variation in $\mathrm{pH}$ between the locations for dry $(6.89 \pm 0.06,6.88 \pm 0.08)$ and wet $(7.44 \pm 0.06,7.65 \pm 0.08)$ seasons. The $\mathrm{pH}$ range of $5.50-8.72$ obtained in this study shows an acidic to alkaline condition for the study locations. The mean values of $7.17 \pm 0.01$ and $7.26 \pm 0.01$ obtained in Ogobiri and Agoro-Gbene locations exhibited slightly alkaline conditions. This agrees with earlier findings from tropical aquatic ecosystems (Welcome, 1986) and Otobo (1995b) who also recorded a $\mathrm{pH}$ of 7.3. The mean $\mathrm{pH}$ values recorded in the locations were within the preferred $\mathrm{pH}$ of $6.5-9.0$ recommended for optimal fish production (Boyd and Lichktopller, 1979). However, the $\mathrm{pH}$ in the dredged location was generally acidic ranging from $6.69-6.93$, acidic sediment can have an adverse effect on fisheries distribution.

The monthly water temperature values ranged between $26.1^{\circ} \mathrm{C}$ and $29.8^{\circ} \mathrm{C}$ across the locations and stations. The mean temperatures were significantly different $(\mathrm{P}<0.05)$ across the stations. There was no significant difference $(\mathrm{P}>0.05)$ in mean temperature in Ogobiri $(27.9 \pm 0.02)$ and Agoro-Gbene $\left(28.2^{0} \mathrm{C} 2 \pm 0.02\right.$ 
locations. There was also no significant $(\mathrm{P}>0.05)$ variation in temperature between the locations for dry $\left(27.4^{0} \mathrm{C}\right.$ $\left.\pm 0.08,28.3^{\circ} \mathrm{C} \pm 0.10\right)$ and wet $\left(28.3^{\circ} \mathrm{C} \pm 0.08,28.2^{\circ} \mathrm{C} \pm 0.10\right)$ seasons. The range of surface water temperature in this study $\left(26.1^{\circ} \mathrm{C}-29.8^{\circ} \mathrm{C}\right)$ is in agreement with Otobo $(1995 \mathrm{~b})$ who reported a range of $26^{\circ} \mathrm{C}-30^{\circ} \mathrm{C}$ for the Nun River. The temperature range is also typical of $25^{\circ} \mathrm{C}-30^{\circ} \mathrm{C}$ in African Rivers (Macan, 1963). It is also within the reported range of $21{ }^{\circ} \mathrm{C}-30{ }^{\circ} \mathrm{C}$ in the Niger Delta (Ewa, 1988; Hutchinson, 1957). These findings agree with earlier works in the Niger Delta waters by Chindah et. al ., (1998) who reported temperature range of between $26{ }^{\circ} \mathrm{C}-30.5^{\circ} \mathrm{C}$; Zabbey (2002) between $26.3^{\circ} \mathrm{C}-30.4$; Braide et al., (2004) $26.64{ }^{\circ} \mathrm{C}-30.8{ }^{\circ} \mathrm{C}$; Ansa (2005) $25.9^{\circ} \mathrm{C}-32.4^{\circ} \mathrm{C}$; Hart and Zabbey $(2005) 25.8^{\circ} \mathrm{C}-27.8^{\circ} \mathrm{C}$; Sikoki and Zabbey (2006) $26^{\circ} \mathrm{C}-27.8^{\circ} \mathrm{C}$; Dibia (2006) $25^{\circ} \mathrm{C}-27^{\circ} \mathrm{C}$; Seiyaboh et al., (2007) $26^{\circ} \mathrm{C}$ and Jamabo (2008) who reported a temperature range of $27^{\circ} \mathrm{C}-30^{\circ} \mathrm{C}$ in the Upper Bonny River of Niger Delta.

The monthly water turbidity values ranged between $22.15 \mathrm{NTU}$ and $125.80 \mathrm{NTU}$ across the locations and stations. The mean turbidity were significantly different $(\mathrm{P}<0.05)$ across the stations. There was significant difference $(\mathrm{P}<0.05)$ in mean turbidity in Ogobiri $(62.54 \mathrm{NTU} \pm 0.64)$ and Agoro-Gbene $(44.25 \mathrm{NTU} \pm 0.81)$ locations. There was significant $(\mathrm{P}<0.05)$ variation in temperature between the locations for dry $(50.76 \mathrm{NTU} \pm 1.50,36.59 \mathrm{NTU} \pm 1.94)$ and wet $(73.91 \mathrm{NTU} \pm 1.55,51.99 \mathrm{NTU} \pm 1.96)$ seasons. The turbidity range of $22.15 \mathrm{NTU}-125.80 \mathrm{NTU}$ observed in this study showed a gradual increase in turbidity values from the upstream stations to downstream stations along the creek. These values were higher than the values obtained by Seiyaboh et. al., (2007) ranging from 5NTU - 64NTU in the Nun River. The mean turbidity value of 62.54NTU recorded in Ogobiri (Dredged) location was significantly higher than 44.25NTU recorded in Agoro-Gbene (Undredged) location. This can be attributed to the dredging operation in the area. The results also showed much higher values for Turbidity in the station immediately downstream of the dredged area and steadily declined further downstream.

The monthly conductivity values ranged between $50.00 \mu \mathrm{hmoscm}^{-1}$ and $167.00 \mu \mathrm{hmoscm}{ }^{-1}$ across the locations and stations. The mean conductivity were significantly different $(\mathrm{P}<0.05)$ across the stations. There was significant difference $(\mathrm{P}<0.05)$ in mean conductivity in Ogobiri $\left(76.23 \mu \mathrm{hmoscm}^{-1} \pm 2.60\right)$ and Agoro-Gbene $\left(65.44 \mu \mathrm{hmoscm}^{-1} \pm 3.29\right)$ locations. There was significant $(\mathrm{P}<0.05)$ variation in conductivity between the locations for dry $\left(85.00 \mu \mathrm{hmoscm}^{-1} \pm 4.30, \quad 76.91 \mu \mathrm{hmoscm}^{-1} \pm 5.56\right)$ and wet $\left(64.47 \mu \mathrm{hmoscm}^{-1} \pm 4.44\right.$, $\left.54.02 \mu \mathrm{hmoscm}^{-1} \pm 5.61\right)$ seasons. The conductivity range $\left(50 \mu \mathrm{hmoscm}^{-1}-167 \mu \mathrm{hmoscm}^{-1}\right)$ obtained in this study compares favorably with the range of $89 \mu \mathrm{hmoscm}^{-1}-110 \mu \mathrm{hmoscm}^{-1}$ recorded for the Nun River around Tombia by Seiyaboh et. al., (2007). However, these values are higher than the range of $30 \mu \mathrm{hmoscm}^{-1}-$ $71 \mu \mathrm{hmoscm}^{-1}$ recorded for the Niger Delta and Otobo (1995b) range of $42 \mu \mathrm{hmoscm}^{-1}-68 \mu \mathrm{hmoscm}^{-1}$ in the Nun River around Polaku. The mean conductivity value of $76.23 \mu \mathrm{hmoscm}^{-1}$ in Ogobiri (Dredged) location was significantly higher than $65.44 \mu \mathrm{hmoscm}^{-1}$ recorded in Agoro-Gbene (Undredged) location. This may be indicative of the impact of dredging.

The monthly DO values ranged between $2.1 \mathrm{mg} / \mathrm{l}$ and $6.5 \mathrm{mg} / \mathrm{l}$ across the locations and stations. The mean DO were significantly different $(\mathrm{P}<0.05)$ across the stations. There was no significant difference $(\mathrm{P}>0.05)$ in mean DO in Ogobiri $(3.7 \mathrm{mg} / 1 \pm 0.03)$ and Agoro-Gbene $(3.4 \mathrm{mg} / 1 \pm 0.04)$ locations. There was also no significant $(\mathrm{P}>0.05)$ variation in DO between the locations for dry $(4.2 \mathrm{mg} / \mathrm{l} \pm 0.07,3.6 \mathrm{mg} / \mathrm{l} \pm 0.09)$ and wet $(3.2 \mathrm{mg} / 1 \pm 0.07,3.1 \mathrm{mg} / 1 \pm 0.09)$ seasons. The DO values ranged between $2.1 \mathrm{mg} / \mathrm{l}-6.5 \mathrm{mg} / \mathrm{l}$ and is close to that obtained by Seiyaboh et. al., (2007) in the Nun River $(3.8 \mathrm{mg} / \mathrm{l}-7.2 \mathrm{mg} / \mathrm{l})$. The higher DO values recorded in the dry season did not agree with the findings of Egborge (1971) who reported that DO is generally higher in the wet season in the tropics. The lowest Do value was recorded at the peak of the wet season and in the dredged location.

The monthly TDS values ranged between $25.00 \mathrm{mg} / \mathrm{l}$ and $85.60 \mathrm{mg} / \mathrm{l}$ across the locations and stations. The mean TDS were significantly different $(\mathrm{P}<0.05)$ across the stations. There was significant difference $(\mathrm{P}<0.05)$ in mean TDS in Ogobiri $(36.18 \mathrm{mg} / \mathrm{l} \pm 0.39)$ and Agoro-Gbene $(32.62 \mathrm{mg} / \mathrm{l} \pm 0.04)$ locations. There was also significant $(\mathrm{P}<0.05)$ variation in TDS between the locations for dry $(43.23 \mathrm{mg} / 1 \pm 0.83,38.20 \mathrm{mg} / \mathrm{l} \pm 1.07)$ and wet $(29.13 \mathrm{mg} / \mathrm{l} \pm 0.86,27.06 \mathrm{mg} / 1 \pm 1.08)$ seasons. The mean TDS value of $36.18 \mathrm{mg} / \mathrm{l}$ in Ogobiri (Dredged) location was significantly higher than $32.67 \mathrm{mg} / \mathrm{l}$ recorded in Agoro-Gbene (Un-dredged) location. This may be attributed to the release of nutrients as a result of re-suspension of sediments during dredging operations.

The monthly $\mathrm{NO}_{3}{ }^{-}$values ranged between $0.023 \mathrm{mg} / \mathrm{l}$ and $0.550 \mathrm{mg} / \mathrm{l}$ across the locations and stations. The mean $\mathrm{NO}_{3}{ }^{-}$values were significantly different $(\mathrm{P}<0.05)$ across the stations. There was significant difference $(\mathrm{P}<0.05)$ in mean $\mathrm{NO}_{3}{ }^{-}$in Ogobiri $(0.132 \mathrm{mg} / 1 \pm 0.22)$ and Agoro-Gbene $(0.205 \mathrm{mg} / 1 \pm 0.22)$ locations. There was also significant $(\mathrm{P}<0.05)$ variation in $\mathrm{NO}_{3}{ }^{-}$between the locations for dry $(0.107 \mathrm{mg} / 1 \pm 0.01,0.271 \mathrm{mg} / 1 \pm 0.01)$ and wet $(0.159 \mathrm{mg} / 1 \pm 0.01,0.142 \mathrm{mg} / \mathrm{l} \pm 0.01)$ seasons. Nitrate values ranged from $0.023 \mathrm{mg} / \mathrm{l}-0.550 \mathrm{mg} / \mathrm{l}$ and were lower than that obtained by Seiyaboh et. al., (2007) in the Nun River $(0.32 \mathrm{mg} / \mathrm{l}-4.15 \mathrm{mg} / \mathrm{l})$. The mean $\mathrm{NO}_{3}{ }^{-}$ value of $0.132 \mathrm{mg} / \mathrm{l}$ in Ogobiri (Dredged) location was significantly lower than $0.205 \mathrm{mg} / \mathrm{l}$ obtained in AgoroGbene (Un-dredged) location. 
The monthly $\mathrm{NO}_{2}{ }^{-}$value $\mathrm{s}$ ranged between $0.021 \mathrm{mg} / \mathrm{l}$ and $0.168 \mathrm{mg} / \mathrm{l}$ across the locations and stations. The mean $\mathrm{NO}_{2}{ }^{-}$values were significantly different $(\mathrm{P}<0.05)$ across the stations. There was significant difference $(\mathrm{P}<0.05)$ in mean $\mathrm{NO}_{2}{ }^{-}$in Ogobiri $(0.090 \mathrm{mg} / \mathrm{l} \pm 0.001)$ and Agoro-Gbene $(0.074 \mathrm{mg} / \mathrm{l} \pm 0.001)$ locations. There was also significant $(\mathrm{P}<0.05)$ variation in $\mathrm{NO}_{2}{ }^{-}$between the locations for dry $(0.084 \mathrm{mg} / 1 \pm 0.003,0.089 \mathrm{mg} / 1 \pm 0.003)$ and wet $(0.096 \mathrm{mg} / 1 \pm 0.003,0.059 \mathrm{mg} / 1 \pm 0.003)$ seasons. The mean $\mathrm{NO}_{2}^{-}$value of $0.090 \mathrm{mg} / 1$ in Ogobiri (Dredged) location) was significantly higher than $0.074 \mathrm{mg} / \mathrm{l}$ obtained in Agoro-Gbene (Un-dredged) location. The results showed higher values for $\mathrm{NO}_{2}^{-}$in the station immediately downstream of the dredged area which steadily declined further downstream. This is indicative of impact of dredging on $\mathrm{NO}_{2}^{-}$level.

The monthly $\mathrm{Cl}^{-}$values ranged between $0.10 \mathrm{mg} / \mathrm{l}$ and $1.09 \mathrm{mg} / \mathrm{l}$ across the locations and stations. The mean $\mathrm{Cl}^{-}$values were significantly different $(\mathrm{P}<0.05)$ across the stations. There was significant difference $(\mathrm{P}<0.05)$ in mean $\mathrm{Cl}^{-}$in Ogobiri $(0.48 \mathrm{mg} / \mathrm{l} \pm 1.09)$ and Agoro-Gbene $(0.41 \mathrm{mg} / 1 \pm 1.37)$ locations. There was no significant $(\mathrm{P}>0.05)$ variation in $\mathrm{Cl}^{-}$between the locations for dry $(0.36 \mathrm{mg} / \mathrm{l} \pm 2.46,0.32 \mathrm{mg} / \mathrm{l} \pm 3.17)$ and wet $(58.81 \mathrm{mg} / 1 \pm 2.53,49.33 \mathrm{mg} / 1 \pm 3.20)$ seasons. The mean $\mathrm{Cl}^{-}$value of $0.48 \mathrm{mg} / \mathrm{l}$ in Ogobiri (Dredged) location was significantly higher than $0.40 \mathrm{mg} / \mathrm{l}$ obtained in Agoro-Gbene (Un-dredged) location.

The monthly $\mathrm{SO}_{4}^{2-}$ values ranged between $3.30 \mathrm{mg} / \mathrm{l}$ and $12.50 \mathrm{mg} / \mathrm{l}$ across the locations and stations. The mean $\mathrm{SO}_{4}{ }^{2-}$ values were significantly different $(\mathrm{P}<0.05)$ across the stations. There was significant difference $(\mathrm{P}<0.05)$ in mean $\mathrm{SO}_{4}^{2-}$ in Ogobiri $(6.83 \mathrm{mg} / \mathrm{l} \pm 0.06)$ and Agoro-Gbene $(8.29 \mathrm{mg} / 1 \pm 0.08)$ locations. There was also significant $(\mathrm{P}<0.05)$ variation in $\mathrm{SO}_{4}{ }^{2-}$ between the locations for dry $(7.50 \mathrm{mg} / 1 \pm 0.14,7.45 \mathrm{mg} / 1 \pm 0.18)$ and wet $(6.16 \mathrm{mg} / \mathrm{l} \pm 0.15,9.12 \mathrm{mg} / \mathrm{l} \pm 0.19)$ seasons. The mean $\mathrm{SO}_{4}{ }^{2-}$ value of $6.83 \mathrm{mg} / \mathrm{l}$ in Ogobiri (Dredged) location) was significantly lower than $8.29 \mathrm{mg} / \mathrm{l}$ obtained in Agoro-Gbene (Un-dredged) location.

The monthly ALK. values ranged between $7.00 \mathrm{mg} / 1$ and $128.00 \mathrm{mg} / 1$ across the locations and stations. The mean ALK. values were significantly different $(\mathrm{P}<0.05)$ across the stations. There was significant difference $(\mathrm{P}<0.05)$ in mean ALK. in Ogobiri $(54.87 \mathrm{mg} / \mathrm{l} \pm 1.06)$ and Agoro-Gbene $(64.12 \mathrm{mg} / \mathrm{l} \pm 1.34)$ locations. There was also significant $(\mathrm{P}<0.05) 1$ variation in ALK. between the locations for dry $(30.38 \mathrm{mg} / \mathrm{l} \pm 2.71$, $40.34 \mathrm{mg} / 1 \pm 3.50)$ and wet $(79.95 \mathrm{mg} / 1 \pm 2.79,87.95 \mathrm{mg} / 1 \pm 3.53)$ seasons.

The monthly $\mathrm{BOD}_{5}$ values ranged between $0.7 \mathrm{mg} / \mathrm{l}$ and $12.7 \mathrm{mg} / \mathrm{l}$ across the locations and stations. The mean $\mathrm{BOD}_{5}$ values were significantly different $(\mathrm{P}<0.05)$ across the stations. There was significant difference $(\mathrm{P}<0.05)$ in mean $\mathrm{BOD}_{5}$ in Ogobiri $(3.6 \mathrm{mg} / \mathrm{l} \pm 0.27)$ and Agoro-Gbene $(4.4 \mathrm{mg} / \mathrm{l} \pm 0.34)$ locations. There was also significant $(\mathrm{P}<0.05)$ variation in $\mathrm{BOD}_{5}$ between the locations for dry $(4.8 \mathrm{mg} / 1 \pm 0.24,7.4 \mathrm{mg} / 1 \pm 0.30)$ and wet $(2.3 \mathrm{mg} / \mathrm{l} \pm 0.24,1.4 \mathrm{mg} / \mathrm{l} \pm 0.31)$ seasons. The $\mathrm{BOD}_{5}$ values ranged from $0.7 \mathrm{mg} / \mathrm{l}-12.7 \mathrm{mg} / \mathrm{l}$ and these values varied considerably from $1.97 \mathrm{mg} / \mathrm{l}-2.69 \mathrm{mg} / \mathrm{g}$ recorded by Abowei \& George (2009) in Okpoka Creek, Niger Delta, Nigeria.

\section{Conclusion}

The results indicate that the watert quality in the Un-dredged location were generally better than in the Dredged location. From the above information, it is concluded that there has been an impact of dredging on the water quality of Igbedi Creek, Upper Nun River.

\section{References}

[1]. Abowei, J. F. N. (2000): Aspects of the fisheries of the lower Nun River. Ph.D. Dissertation, University of Port Harcourt. 180pp.

[2]. Abowei, J. F. N. and George, A. D. I. (2009). Some physical and chemical characteristics in Okpoka Creek, Niger Delta, Nigeria. Research Journal of Environmental and Earth Sciences 1(2):45-53.

[3]. APHA, (1998). Standard Methods for the Examination of Water and Waste Waters. $\quad 19^{\text {th }}$ ed. APHA-AWA $\quad$ WPCF. Washington DC. Pp. 1007-1151

[4]. Ansa, E. J. (2005). Studies of the benthic macrofauna of the Andoni flats in the Niger Delta Area of Nigeria. Ph.D. Thesis University of Port Harcourt, Nigeria, pp: 242

[5]. Boyd, C. E. and Lichtkoppler, F. (1979). Water quality management in fishpond, Research and Dev. Series No. 22. International centre for Aquaculture and Agriculture (I. C. C. A.). Experimental Station Auburn University, Alabama, pp: 45-47.

[6]. Braide, S. A., Izonfuo, W. A. L., Adiukwu, P. U., Chindah, A. C. and Obunwo, C. C. (2004). Water Quality of Miniweja stream, A swamp forest stream receiving non-point source waste discharges in Eastern Niger Delta, Nigeria. Scientia Africana, 3(1): 1-8.

[7]. Chindah, A. C., Braide, S. A. and Obunwo, C. (1998). The effect of municipal waste chemical and phytoplankton in a brackish wetland in Bonny Estuary. Acts

[8]. Dibia, A. E. N. (2006). Effect of biotope difference on aquatic Macrophytes along Harcourt, Rivers State. M.Sc. Thesis, Rive State University of Science and $120 \mathrm{p}$.

[9]. DSE (2011) Coasts and Marine: Coasts - Dredging. Department of Sustainability and Victoria,USA, 1996 - 2012. Pp 1-3

[10]. Egborge, A. B. M. (1971). The chemical hydrology of River Oshun, Western State, 271.

[11]. Ewa, I. O. (1988). Effects of simulated crude oil spills on a mangrove swamp of Bonny estuary. M.
Rivers State University of Science and $\quad$ Technology. 
Impact of Dredging on the Water Quality of Igbedi Creek, Upper Nun River, Niger Delta, Nigeria

[12]. Hart, A. I. and Zabbey, N. (2005). Physico-chemical and benthic fauna of Woji Creek in the Lower Niger Delta, Nigeria. Environ. Ecol., 23(2): 361-368.

[13]. Hutchinson, G. E. (1957). A Treatise on Limnology 1: Geography, Physics and Chemistry John

[14]. Jamabo, N. A. (2008). Ecology of Tympanotonus fuscatus (Linnaeus, 1758) in the mangrove Wiley, New York 1015p. Bonny River, Niger Delta, Nigeria. Ph.D. Thesis, Rivers State University of Science and Technology, 340p.

[15]. Macan, T. T. (1963). Freshwater Ecology $2^{\text {nd }}$ Ed. Longman Group Ltd.

[16]. Moyle, P.B. and Leidy, R.A (1992) Loss of aquatic ecosystem: Evidence from fish faunas. Pages 127-169 in P.L. Fielder and S,K, Jain, ed. Conservative Biology. The Theory and Practice of Nature Conservation, Preservation and Management. Chapman and Hall, New York.

[17]. Onyeike, E.N. and Osuji, J.O. (2003) Research Techniques in Biological and Chemical Sciences. Springfield Publishers, Imo State, Nigeria. pp 172-189.

[18]. Otobo, A. J. T. (1993) The ecology and fishery of the pygmy herring Sierratherissa leonensis (Thys Van Den Audenaerde, 1969) (Clupeidae) in the Nun River and Taylor Creek of the Niger Delta. Ph.D. Thesis University of Port Harcourt, 45-48pp.

[19]. Otobo, A. J. T., (1995a) Fisheries issues in the Niger Delta. An invited paper presented at the National workshop on Environmental Development strategy for the Niger Delta of Nigeria [FOR]

[20]. Otobo, A. J. T., (1995b) The ecology and fishery of the Pygmy herring Sierrathrissa leonesis Thus Van Den Audernaerade, 1969 (Clupeidae) in the Nun Rivers and Taylor Creek of the Niger Delta. Ph.D. Thesis University of Port Harcourt. 207pp. [AQF], [FISR].

[21]. Seiyaboh, E.I., Ekweozor, I.K.E., Ogamba, E.N. and Alagha, W.E. (2007) Effect of Tombia bridge construction on the water quality of Nun River in Central Niger Delta, Nigeria. Journal of applied sciences.10:3, 2007.

[22]. Sikoki, F. D. and Otobotekere, A. J. T. (1999). Fisheries in Alagoa E. J. (Ed.). The Land and People of Bayelsa State: Central Niger Delta. Onyoma Research Publications, Choba Port Harcourt.,

[23]. Sikoki, F. D. and Zabbey, N. (2006). Environmental gradients and Benthic community River, South-Eastern Nigeria. Environ. Ecol. 24(1): 32- 36.

[24]. Welcome, R. L. (1986). The Niger River System. London Longman Group Ltd. Pp. 9-

[25]. Whittier, T., Halliwell, D.B. and Oaykseb, S,G, (1997) Cyprinids distributions in regional-scale minnows biodiversity losses. C Con. J. Fish Aquat. Sci., 54: 1593-1807.

[26]. WHO, (2011) World Health Organisation. The International Standards for drinking

[27]. Zabbey, N. (2002). An ecological survey of benthic macroinvertebrates of Woji Creek, Rivers State. M.Sc. Thesis, University of Port Harcourt. Pp:102

$$
\text { of the middle reaches of Imo }
$$

23.

Northeast USA lakesL evidence of

water quality, Geneva

off the Bonny River System,

Table 1: Mean Physico-Chemical Characteristics of water Samples in Ogobiri Location

\begin{tabular}{|c|c|c|c|c|c|}
\hline Parameters & $\mathrm{OGO}_{1} \mathrm{DA}$ & $\mathrm{OGO}_{1} \mathrm{DS}$ & $\mathrm{OGO}_{2} \mathrm{DS}$ & $\mathrm{OGO}_{1} \mathrm{US}$ & $\mathrm{OGO}_{2} \mathrm{CO}$ \\
\hline DEPTH (m) & $9.43 \pm 1.19^{a}$ & $8.88 \pm 1.10^{\mathrm{a}}$ & $9.32 \pm 1.10^{a}$ & $8.27 \pm 1.15^{a}$ & $6.58 \pm 1.12^{a}$ \\
\hline CUR. VEL. $\mathrm{ms}^{-1}$ & $0.16 \pm 0.01^{\mathrm{a}}$ & $0.16 \pm 0.01^{\mathrm{ab}}$ & $0.57 \pm 0.01^{\mathrm{ab}}$ & $0.19 \pm 0.01^{b}$ & $0.11 \pm 0.01^{\mathrm{ab}}$ \\
\hline PH & $7.20 \pm 0.03^{\mathrm{ab}}$ & $7.11 \pm 0.02^{b}$ & $7.22 \pm 0.02^{\mathrm{ab}}$ & $7.18 \pm 0.02^{\mathrm{b}}$ & $7.12 \pm 0.03^{\text {ba }}$ \\
\hline TEMP ${ }^{0} \mathrm{C}$ & $27.93 \pm 0.05^{b}$ & $28.28 \pm 0.04^{d}$ & $27.87 .0 .04^{c}$ & $27.92 \pm 0.04^{\mathrm{cd}}$ & $27.51 \pm 0.04^{a}$ \\
\hline TURB. NTU & $82.32 \pm 1.40^{d}$ & $71.21 \pm 1.38^{\mathrm{c}}$ & $53.76 \pm 1.38^{\mathrm{a}}$ & $54.76 \pm 1.44^{\mathrm{b}}$ & $50.63 \pm 1.41^{b}$ \\
\hline COND. $\mu \mathrm{hmoscm}^{-1}$ & $76.51 \pm 6.11^{\mathrm{ab}}$ & $69.35 \pm 5.65^{\mathrm{a}}$ & $68.96 \pm 5.65^{a}$ & $68.94 \pm 5.88^{\mathrm{a}}$ & $97.41 \pm 5.77^{b}$ \\
\hline DO mg/l & $3.9 \pm 0.08^{b}$ & $4.1 \pm 0.07^{b}$ & $3.5 \pm 0.07^{\mathrm{a}}$ & $3.3 \pm 0.07^{\mathrm{a}}$ & $3.8 \pm 0.07^{\mathrm{b}}$ \\
\hline TDS mg/l & $39.48 \pm 0.92^{c}$ & $35.10 \pm 0.88^{\mathrm{a}}$ & $35.10 \pm 0.85^{\mathrm{ab}}$ & $35.07 \pm 0.88^{\mathrm{ab}}$ & $36.26 \pm 0.87^{b}$ \\
\hline $\mathrm{NO}_{3}{ }^{-} \mathrm{mg} / \mathrm{l}$ & $0.143 \pm 0.004^{b}$ & $0.196 \pm 0.003^{c d}$ & $0.105 \pm 0.003^{c}$ & $0.170 \pm 0.004^{d}$ & $0.092 \pm 0.004^{a}$ \\
\hline $\mathrm{NO}_{2}^{-} \mathrm{mg} / \mathrm{l}$ & $0.080 \pm 0.002^{b}$ & $0.108 \pm 0.001^{\mathrm{c}}$ & $0.106 \pm 0.001^{c}$ & $0.095 \pm 0.001^{c}$ & $0.060 \pm 0.001^{a}$ \\
\hline $\mathrm{Cl}^{-} \mathrm{mg} / \mathrm{l}$ & $0.44 \pm 2.55^{\mathrm{a}}$ & $0.64 \pm 2.36^{\mathrm{b}}$ & $0.41 \pm 2.36^{\mathrm{a}}$ & $0.46 \pm 2.45^{a}$ & $0.46 \pm 2.41^{a}$ \\
\hline $\mathrm{SO}_{4}{ }^{2-} \mathrm{mg} / \mathrm{l}$ & $7.53 \pm 0.15 b^{c}$ & $7.24 \pm 0.14^{c}$ & $7.06 \pm 0.14^{b}$ & $6.09 \pm 0.14^{b}$ & $6.22 \pm 0.14^{a}$ \\
\hline ALK mg/l & $52.83 \pm 2.49^{a}$ & $50.64 \pm 2.31^{\mathrm{ab}}$ & $51.81 \pm 2.31^{\mathrm{ab}}$ & $57.28 \pm 2.40^{b}$ & $61.88 \pm 2.35^{b}$ \\
\hline BOD $^{5} \mathrm{mg} / \mathrm{l}$ & $3.8 \pm 0.06^{c}$ & $4.2 \pm 0.06^{d}$ & $3.8 \pm 0.06^{\mathrm{c}}$ & $2.4 \pm 0.06^{\mathrm{a}}$ & $3.6 \pm 0.06^{b}$ \\
\hline
\end{tabular}

Key: $\mathrm{OGO}_{1} \mathrm{DA}=$Dredged Area, OGO $_{1 \& 2} \mathrm{DS}=$ Downstream, OGO ${ }_{1 \& 2} \mathrm{US}=\mathrm{Upstream}$

Table 2: Mean Physico-Chemical Characteristics of water Samples in Agoro-Gbene Location

\begin{tabular}{|c|c|c|c|}
\hline Parameters & $\mathrm{OGO}_{1} \mathrm{DS}$ & $\mathrm{OGO}_{1} \mathrm{MD}$ & $\mathrm{OGO}_{1} \mathrm{US}$ \\
\hline DEPTH (m) & $6.92 \pm 1.12^{\mathrm{a}}$ & $6.92 \pm 1.12^{a}$ & $6.92 \pm 1.12^{a}$ \\
\hline CUR. VEL. ms- ${ }^{1}$ & $0.192 \pm 0.01^{a b}$ & $0.194 \pm 0.01^{a b}$ & $0.21 \pm 0.01^{\mathrm{b}}$ \\
\hline PH & $7.15 \pm 0.03^{\mathrm{ab}}$ & $7.32 \pm 0.02^{b}$ & $7.29 \pm 0.02^{b}$ \\
\hline TEMP ${ }^{0} \mathrm{C}$ & $28.19 \pm 0.04^{c}$ & $28.23 \pm 0.04^{d}$ & $28.24 \pm 0.04^{c d}$ \\
\hline TURB. NTU & $35.95 \pm 1.41^{\mathrm{a}}$ & $48.49 \pm 1.38^{c}$ & $48.31 \pm 1.38^{b}$ \\
\hline COND. $\mu \mathrm{hmoscm}^{-1}$ & $66.47 \pm 5.77^{\mathrm{a}}$ & $64.91 \pm 5.15^{\mathrm{a}}$ & $64.93 \pm 5.65^{\mathrm{a}}$ \\
\hline DO mg/l & $2.9 \pm 0.07^{\mathrm{a}}$ & $2.7 \pm 0.07^{b}$ & $3.5 \pm 0.07^{\mathrm{a}}$ \\
\hline TDS mg/l & $33.31 \pm 0.87^{\mathrm{ab}}$ & $31.93 \pm 0.85^{a}$ & $32.61 \pm 0.85^{\mathrm{ab}}$ \\
\hline $\mathrm{NO}_{3}{ }^{-} \mathrm{mg} / \mathrm{l}$ & $0.226 \pm 0.004^{c}$ & $0.196 \pm 0.003^{\text {cd }}$ & $0.192 \pm 0.003^{d}$ \\
\hline $\mathrm{NO}_{2}^{-} \mathrm{mg} / \mathrm{l}$ & $0.074 \pm 0.001^{c}$ & $0.070 \pm 0.001^{c}$ & $0.079 \pm 0.001^{c}$ \\
\hline $\mathrm{Cl}^{-} \mathrm{mg} / \mathrm{l}$ & $0.43 \pm 2.41^{\mathrm{a}}$ & $0.44 \pm 2.36^{b}$ & $0.36 \pm 2.36^{\mathrm{a}}$ \\
\hline $\mathrm{SO}_{4}{ }^{2-} \mathrm{mg} / \mathrm{l}$ & $7.42 \pm 0.14^{b}$ & $8.83 \pm 0.14^{c}$ & $8.14 \pm 0.14^{b}$ \\
\hline ALK mg/l & $64.65 \pm 2.35^{\mathrm{ab}}$ & $60.08 \pm 2.31^{\mathrm{ab}}$ & $67.61 \pm 2.31^{b}$ \\
\hline BOD $^{5} \quad \mathrm{mg} / \mathrm{l}$ & $4.1 \pm 0.06^{c}$ & $4.7 \pm 0.06^{d}$ & $4.4 \pm 0.06^{\mathrm{a}}$ \\
\hline
\end{tabular}

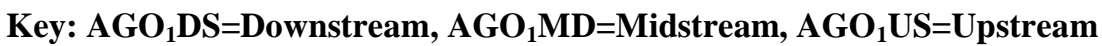


Table 3: Seasonal Mean for Ogobiri \& Agoro-Gbene Locations (Water)

\begin{tabular}{|c|c|c|c|c|}
\hline PARAMETERS & AGO DRY & AGO WET & OGO DRY & OGO WET \\
\hline DEPTH (M & $6.34 \pm 0.90$ & $8.11 \pm 0.91$ & $7.36 \pm 0.70$ & $9.62 \pm 0.72$ \\
\hline CUR. VEL. ms-1 & $0.18 \pm 0.01$ & $0.22 \pm 0.01$ & $0.14 \pm 0.01$ & $0.19 \pm 0.01$ \\
\hline PH & $6.88 \pm 0.08$ & $7.65 \pm 0.08$ & $6.89 \pm 0.06$ & $7.44 \pm 0.06$ \\
\hline TEMP ${ }^{0} \mathrm{C}$ & $28.27 \pm 0.10$ & $28.17 \pm 0.10$ & $27.41 \pm 0.08$ & $28.33 \pm 0.08$ \\
\hline TURB. NTU & $36.59 \pm 1.94$ & $51.99 \pm 1.96$ & $50.76 \pm 1.50$ & $73.91 \pm 1.55$ \\
\hline COND. $\mu \mathrm{hmoscm}{ }^{-1}$ & $76.91 \pm 5.56$ & $54.02 \pm 5.61$ & $85.00 \pm 4.30$ & $64.47 \pm 4.44$ \\
\hline DO mg/l & $3.6 \pm 0.09$ & $3.1 \pm 0.09$ & $4.2 \pm 0.07$ & $3.2 \pm 0.07$ \\
\hline TDS mg/l & $38.20 \pm 1.07$ & $27.06 \pm 1.08$ & $43.23 \pm 0.83$ & $29.13 \pm 0.86$ \\
\hline $\mathrm{NO}_{3}{ }^{-} \mathrm{mg} / \mathrm{l}$ & $0.271 \pm 0.01$ & $0.142 \pm 0.01$ & $0.107 \pm 0.01$ & $0.159 \pm 0.01$ \\
\hline $\mathrm{NO}_{2}^{-} \mathrm{mg} / \mathrm{l}$ & $0.089 \pm 0.003$ & $0.059 \pm 0.003$ & $0.084 \pm 0.003$ & $0.096 \pm 0.003$ \\
\hline $\mathrm{Cl}^{-} \mathrm{mg} / \mathrm{l}$ & $0.32 \pm 3.17$ & $0.49 \pm 3.20$ & $0.36 \pm 2.46$ & $0.59 \pm 2.53$ \\
\hline $\mathrm{SO}_{4}{ }^{2-} \mathrm{mg} / \mathrm{l}$ & $7.45 \pm 0.18$ & $9.12 \pm 0.19$ & $7.50 \pm 0.14$ & $6.16 \pm 0.15$ \\
\hline ALK mg/l & $40.34 \pm 3.50$ & $87.95 \pm 3.53$ & $30.38 \pm 2.71$ & $79.95 \pm 2.79$ \\
\hline BOD $^{5} \mathrm{mg} / \mathrm{l}$ & $7.4 \pm 0.30$ & $1.4 \pm 0.31$ & $4.8 \pm 0.24$ & $2.3 \pm 0.24$ \\
\hline
\end{tabular}

